\title{
C9orf72 wt Allele
}

National Cancer Institute

\section{Source}

National Cancer Institute. C9orf72 wt Allele. NCI Thesaurus. Code C101399.

Human C9orf72 wild-type allele is located in the vicinity of 9p21.1 and is approximately 27 $\mathrm{kb}$ in length. This allele, which encodes uncharacterized protein C9orf72, may be involved in cell death. An expanded GGGGCC hexanucleotide repeat in the non-coding region of the C9orf72 gene is associated with amyotrophic lateral sclerosis and frontotemporal dementia. 